\title{
Protein PEGylation for the design of biobetters: from reaction to purification processes
}

\author{
João Henrique Picado Madalena Santos ${ }^{1,2}$, Karin Mariana Torres-Obreque ${ }^{1}$, Giovanna Pastore \\ Meneguetti $^{1}$, Beatriz Panichi Amaro ${ }^{1}$, Carlota Oliveira Rangel-Yagui ${ }^{*}$
}

\begin{abstract}
${ }^{1}$ Department of Biochemical-Pharmaceutical Technology, School of Pharmaceutical Sciences, University of São Paulo, São Paulo, Brazil, ${ }^{2}$ CICECO - Department of Chemistry, Aveiro Institute of Materials, University of Aveiro, Aveiro, Portugal
\end{abstract}

\begin{abstract}
The covalent attachment of polyethylene glycol (PEG) to therapeutical proteins is an important route to develop biobetters for biomedical, biotech and pharmaceutical industries. PEG conjugation can shield antigenic epitopes of the protein, reduce degradation by proteolytic enzymes, enhance long-term stability and maintain or even improve pharmacokinetic and pharmacodynamics characteristics of the protein drug. Nonetheless, correct information in terms of the PEGylation process from reaction to downstream processing is of paramount importance for the industrial application and processing scale-up. In this review we present and discuss the main steps in protein PEGylation, namely: PEGylation reaction, separation of the products and final characterization of structure and activity of the resulting species. These steps are not trivial tasks, reason why bioprocessing operations based on PEGylated proteins relies on the use of analytical tools according to the specific pharmaceutical conjugate that is being developed. Therefore, the appropriate selection of the technical and analytical methods may ensure success in implementing a feasible industrial process.
\end{abstract}

Keywords: PEGylation. Biobetters. Biological drugs. Polyethylene glycol. Protein purification. Sitespecific PEGylation.

\section{PEGYLATION FOR BIOBETTERS DEVELOP- MENT AND PRODUCTION}

Therapies based on biological drugs represented a revolutionary innovation in the pharmaceutical industry due to the success to overcome medical challenges, such as haemophilia, diabetes, arthritis and diseases of the immune system. Because of patent protection strategies and the high market price of biological drugs, the holding companies of innovative molecules generated considerable revenue (Calo-Fernández, Martínez-Hurtado, 2012). In 2016, global market of biological drugs reached US\$ 209.8 billion (Transparency Market Research, 2016) and Roche ${ }^{\circledR}$ was the company with the highest income, reaching US \$ 38.7 billion in 2015 (Spadiut et al., 2014). However, some drawbacks are intrinsically related to biological drugs, more specifically to protein drugs that usually present immunogenicity and short plasma half-life.

\footnotetext{
*Correspondence: C. O. Rangel-Yagui. Departamento de Tecnologia Bioquímico-Farmacêutica, Faculdade de Ciências Farmacêuticas, Universidade de São Paulo.E-mail: corangel@usp.br
}

The immunogenicity is mainly related to the production of anti-drug antibodies (ADA) that reduce clinical efficacy by biological activity neutralization or induction of hypersensitivity, which includes anaphylactic reactions (Barbosa et al., 2012; Kuriakose, Chirmule, Nair, 2016). The shorter biological half-life of protein drugs leads to more recurrent administrations to achieve the desired clinical effect in patients (Ryu, Kim, Nam, 2012). Another concern related to commercial protein drugs is of economic nature and is called "Patent Cliff", a market phenomenon well described for chemical drugs that is happening with biological ones (Calo-Fernández, Martínez-Hurtado, 2012). It refers to a sharp drop in sales of blockbusters following the end of their patent protection, which can impact negatively or positively the main participants in the biological drug industry, depending on the marketing strategies adopted (Calo-Fernández, Martínez-Hurtado, 2012).

Considering the economic need to remain competitive in the market and the necessity to solve the inherent problems of biological drugs, a new generation of protein-based medicines emerge: the follow-on 
biologics. This new generation of biological drugs is divided in two main groups: the biosimilars (Barbosa et al., 2012; Calo-Fernández, Martínez-Hurtado, 2012) and biobetters (Ryu, Kim, Nam, 2012; Gorham, 2015). Both biosimilars and biobetters are similar to a reference product; however, biosimilars aim to establish similarity to a known biological, whereas biobetters seek superiority in one or various aspects of their clinical profile (Sassi et al., 2015). In this sense, biosimilars have the same amino acid sequence of the originator biological drug, and must have also the same safety, purity and efficacy profile (Beck, Sanglier-Cianférani, Van Dorsselaer, 2012). On the other hand, a biobetter is a biological molecule that suffered chemical or molecular modifications from an originator to generate functional changes that include increased halflife, reduced toxicity, reduced immunogenicity and/or enhanced pharmacodynamics (Beck, Sanglier-Cianférani, Van Dorsselaer, 2012; Sassi et al., 2015).

Biobetters represent an opportunity for innovation with reduced risk and increased sales for manufacturers, since the mechanism of action of the originator molecule is already known. At the same time, they promote an improved treatment for patients and possibility of cost reduction for health systems. One of the main tools for the development of biobetters refers to PEGylation, a technique in which at least one chain of polyethylene glycol (PEG) is covalently attached to the structure of the protein (Figure 1) (Hoffman, 2016). PEG is a biocompatible polymer, which presents minor immunogenicity, antigenicity and toxicity, is soluble in water and other organic solvents, is readily cleared from the body and has high mobility in solution, making this the polymer of choice for bioconjugation (Jevševar, Kunstelj, Porekar, 2010). Additionally, PEG is one of the few synthetic polymers approved by the US FDA for internal administration. After the first report of protein PEGylation in the 1970s (Hoffman, 2016), many proteins and peptides have been covalently conjugated with PEG and many more are currently under clinical trials. To date, 14 biobetters (PEGylated proteins, peptides, antibody

(A)

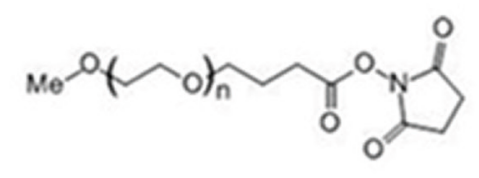

fragments, and oligonucleotides) have been approved by FDA and are currently on the market (Table I). From these, 12 are PEGylated proteins, with a total market value of over US $\$ 8$ billion per year (Ginn et al., 2014).

PEGylation technology was firstly reported in 1977 (Abuchowski et al., 1977) for the modification of albumin and catalase. Depending on the number, molecular weight and location of the attached PEG chains, this covalent modification can enhance the physicochemical properties of the protein, without compromising the secondary structure (González-Valdez, Rito-Palomares, Benavides, 2012). The PEGylation strategy provides a number of advantages for protein conjugates, such as (i) protection of antigenic sites present on the protein surface, i.e. antigenic epitopes; (ii) prevention of in vivo degradation by endocytosis and proteolytic enzymes; (iii) increase in apparent protein size and hydrodynamic volume, which reduces renal filtration, alters biodistribution and increases in vivo half-life; (iv) increased water solubility and reduction of protein aggregates due to steric repulsion between the PEGylated surfaces; (v) increased thermal and long-term stability (Beck, Sanglier-Cianférani, Van Dorsselaer, 2012; Sassi, Nagarkar, Hamblin, 2015). It may also promote sustained release of originator drug (Monfardini et al., 1995; Veronese, Caliceti, Schiavon, 1997).

Several studies have focused on the use of protein PEGylation to develop novel biobetters. A thorough survey of the scientific literature from 1991 to November of 2017 yielded 1450 articles in which protein PEGylation was used in biobetter development (Figure 2). Therefore, it is undeniable that PEGylation is a hot-topic in the biopharmaceutical field. In this paper, we review the main concepts, strategies and pitfalls of protein PEGylation aiming at biobetter manufacturing.

\section{PEGYLATION REACTION DESIGN}

Selecting the appropriate chemistry reaction in the design of PEGylated molecules is the first step in obtaining

(B)

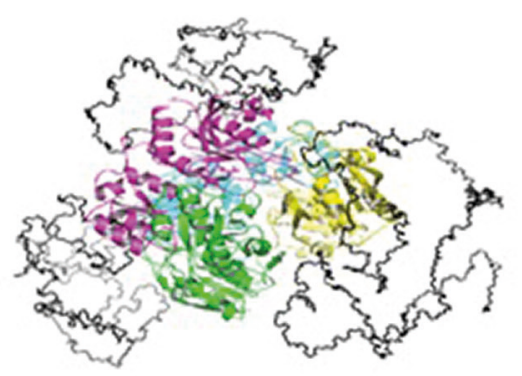

FIGURE 1 - (A) Chemical structure of N-terminal reactive PEG and (B) schematic representation of a tetrameric protein PEGylated with 10,000 Da PEG chains at the $N$-terminal groups. 
Protein PEGylation for the design of biobetters: from reaction to purification processes

TABLE I - FDA-approved biotherapeutics PEGylated drugs in United and States and/or Europe

\begin{tabular}{|c|c|c|c|c|c|}
\hline Brand name, generic name & Company & PEGylation site & $\begin{array}{l}\text { PEG size } \\
\text { (Da) }\end{array}$ & Indication(s) & $\begin{array}{c}\text { Year of } \\
\text { approval }\end{array}$ \\
\hline Adagen $\AA$, pegademase bovine & Enzon & Lysines & 5000 & $\begin{array}{c}\text { Severe combined } \\
\text { immunodeficiency diseases } \\
\text { (SCID) } \\
\end{array}$ & 1990 \\
\hline Oncaspar ${ }^{\circledR}$, pegaspargase & Enzon & Lysines & 5000 & $\begin{array}{c}\text { Acute lymphoblastic leukemia } \\
\text { (ALL) }\end{array}$ & 1994 \\
\hline $\begin{array}{l}\text { PEG-INTRON } \AA \text {, } \\
\text { PEGinterferon alpha } 2 b\end{array}$ & $\begin{array}{l}\text { Schering- } \\
\text { Plough }\end{array}$ & $\begin{array}{l}\text { Histidine, cysteine, } \\
\text { lysines, serine, } \\
\text { tyrosine, histidine }\end{array}$ & 12,000 & Hepatitis C & 2000 \\
\hline $\begin{array}{l}\text { PEGASYS®, PEGinterferon } \\
\text { alpha } 2 \mathrm{a}\end{array}$ & $\begin{array}{l}\text { Hoffman-La } \\
\text { Roche }\end{array}$ & Lysines & 40,000 & Hepatitis C & 2001 \\
\hline Neulasta $\AA$, pegfilgrastim & Amgen & $N$-terminal & 20,000 & Neutropenia & 2002 \\
\hline Somavert $\AA$, pegvisomant & Pfizer & Lysines, $N$-terminal & 5000 & Acromegaly & 2003 \\
\hline Macugen $\AA$, pegaptanib & Pfizer & Lysines & 40,000 & $\begin{array}{l}\text { Age-related macular } \\
\text { degeneration }\end{array}$ & 2004 \\
\hline Mircera ${ }^{\circledR}$, PEG-epoetin beta & $\begin{array}{l}\text { Hoffman-La } \\
\text { Roche }\end{array}$ & Lysines & 30,000 & $\begin{array}{l}\text { Anemia associated with } \\
\text { chronic renal failure }\end{array}$ & 2007 \\
\hline Cimzia ${ }^{\circledR}$, certolizumab pegol & $\mathrm{UCB}$ & $C$-terminal & 40,000 & $\begin{array}{c}\text { Chronic, moderate to severe } \\
\text { RA, Crohn's disease, axial } \\
\text { spondyloarthritis and psoriatic } \\
\text { arthritis }\end{array}$ & 2008 \\
\hline Krystexxa $\AA$, pegloticase & Savient & Lysines & 10,000 & Chronic gout & 2010 \\
\hline $\begin{array}{l}\text { Sylatron }^{\mathrm{TM}}, \text { PEGinterferon }^{1} \\
\text { alpha } 2 \mathrm{~b}\end{array}$ & Merck & $\begin{array}{l}\text { Histidine, cysteine, } \\
\text { lysines, serine, } \\
\text { tyrosine, histidine }\end{array}$ & 12,000 & Melanoma & 2011 \\
\hline Omontys $\AA$, peginesatide & $\begin{array}{l}\text { Affymax/ } \\
\text { Takeda }\end{array}$ & Lysines & 40,000 & $\begin{array}{l}\text { Anemia associated with } \\
\text { chronic kidney disease }\end{array}$ & 2012 \\
\hline $\begin{array}{l}\text { Plegridy }{ }^{\circledR} \text {, peginterferon } \\
\text { beta-1 }\end{array}$ & Biogen & $N$-terminal & 20,000 & Multiple sclerosis & 2014 \\
\hline $\begin{array}{l}\text { Adynovate }{ }^{\circledR} \text {, pegylated } \\
\text { antihemophilic factor }\end{array}$ & Baxalta & Lysines & 20,000 & Hemophilia A & 2015 \\
\hline
\end{tabular}

${ }^{1}$ Sylatron $^{\mathrm{TM}}$ is another brand name for peginterferon alfa-2b exclusively approved by FDA for adjuvant therapy in cancer treatment.

a successful process (Pasut, Veronese, 2012; Pfister and Morbidelli 2014). PEGylation reactions have been extensively reviewed in literature (Jevševar, Kunstelj, Porekar, 2010; Palm, Esfandiary, Gandhi, 2011; Pasut, Veronese, 2012; Ginn et al., 2014; Pfister, Morbidelli, 2014). The selection of the PEG derivative (the reactive PEG used in the PEGylation reaction) is fundamental, since it depends strongly on the location and number of amino-acids that are able to be PEGylated (Veronese, 2001; Zhou, He, Wang, 2016). Generally, the reactive groups in proteins that covalently bind with activated PEG molecules are nucleophiles (Da Silva Freitas, Mero, Pasut, 2013; Zhou, He, Wang, 2016), with the following moieties ranked in decreasing order of reactivity: thiol, $\alpha$-amino, $\varepsilon$-amino, carboxyl, and hydroxyl (González-Valdez et al., 2012). Moreover, the number and local reactivity of the available PEGylation sites (nucleophilic groups of the amino-acids), the experimental conditions of PEGylation reaction (i.e. $\mathrm{pH}$, temperature, reaction time and molar ratio between PEG derivative and protein), and reactivity of the PEG derivative influence the final composition of PEGylated products (González-Valdez et al., 2012). PEG coupling may result in heterogeneous mixtures of PEGylated conjugates with several degrees of PEGylation and non-PEGylated forms (Pasut, Veronese, 2012).

PEGylation reactions are preferably conducted in a single-step unidirectional batch system to guarantee batch-to-batch control and the formation of all products in 


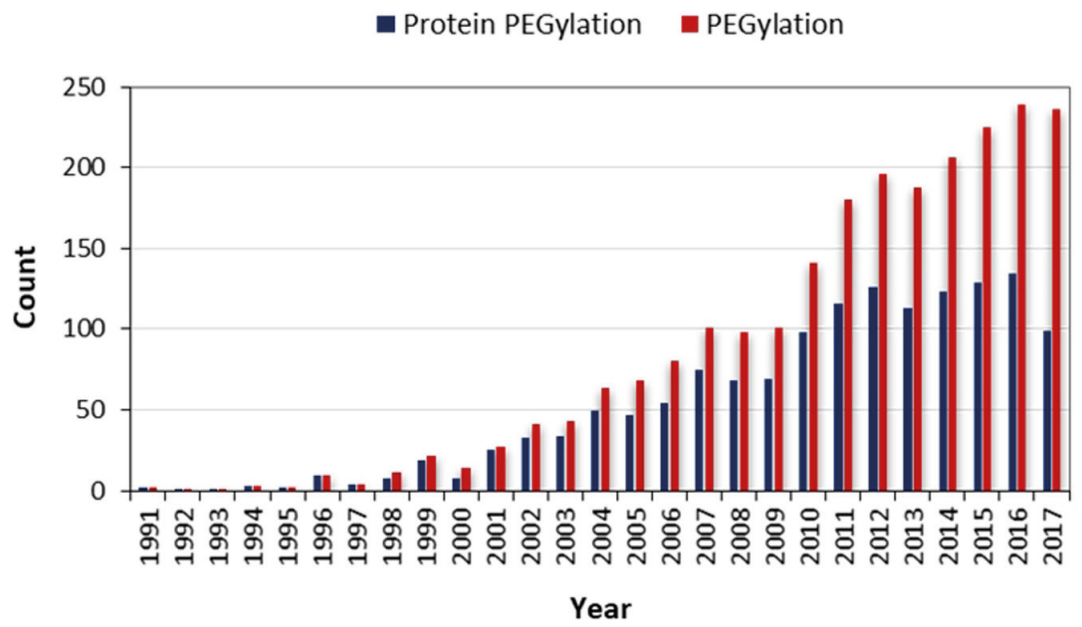

FIGURE 2 - PubMed citations of the title words "Protein PEGylation" and "PEGylation" in published articles in the last 26 years (from 1991 to 2017).

equal conditions. In this sense, validation, reproducibility and optimization of the reaction are favoured, while enabling to easily trace the potential formation of undesirable products (i.e. PEGylation adducts) (González-Valdez et al., 2012). Also, maximization of the PEGylation yield and specificity of every reaction is required. The main challenges of PEGylation are (i) the design of site-specific PEGylation reactions to avoid heterogeneity of PEGylated conjugates; (ii) to obtain shortened-time reactions that increase PEGylation productivity; (iii) to decrease the amount of reactive PEG and the overall cost of the process.

Reactive PEGs for random PEGylation usually target amino groups of the protein, most frequently the $\varepsilon$-amino of the side-chains of lysine residues. Examples of randomly PEGylated biobetters available in the market are Adagen ${ }^{\circledR}$ and Oncaspar ${ }^{\circledR}$ (Table I), which are both complex mixtures of various PEGylated conjugates (higher polydispersity) at lysine residues and $\mathrm{N}$-terminals. PEG-INTRON ${ }^{\circledR}\left(\right.$ Sylatron $\left.^{\mathrm{TM}}\right)$, PEGASYS ${ }^{\circledR}$, Mircera ${ }^{\circledR}$ are also examples of randomly PEGylated drugs (Table I), but in this case they are mixtures of mono-PEGylated positional isomers exhibiting extended half-lifes in comparison to the originator drugs. PEGylation reactions can be directed towards the formation of site-specific PEGylated conjugates by the optimization of reaction conditions (Veronese, 2001; Zhao et al., 2012; Da Silva Freitas, Mero, Pasut, 2013). An example of a site-specific PEGylated biobetter available in the market is Neulasta ${ }^{\circledR}$ (Table I), an N-terminally mono-PEGylated granulocytecolony stimulating factor (G-CSF).

PEGylation of therapeutic proteins usually involves the use of mono-methoxy PEG (mPEG), approved by FDA and EMA. Since it has only one reactive hydroxyl group, undesirable byproducts, i.e. crossed linked products, are avoided. (Jevševar, Kunstelj, Porekar, 2010; Sassi, Nagarkar, Hamblin, 2015) One of the most common mPEG is the amino reactive $\mathrm{N}$-hydroxylsuccinimide (NHS) functionalized polyethylene glycol (PEG-NHS), used to modify proteins, peptides or any molecule/ structure with available amino groups. The reaction of NHS esters with primary amine groups at $\mathrm{pH} 7-8.5$ results in stable amide bonds. Compared to other PEG NHS ester derivatives, the succinimidyl carbonate (SC) functionalized mPEG-NHS offers superior reactivity and higher stability in aqueous solution (Nanocs, 2017).

In PEGylation, linear PEGs are the conventional and simplest conjugate agents (Figure 3 ). With this type of PEGs, proteins are conjugated in the distal end of a PEG molecule in a single attachment site (Roberts, Bentley, Harris, 2012). Bifunctional PEGs are linear PEGs with two available sites for protein conjugation, meaning that in maximum only two biomolecules may be conjugated, which limits the loading capacity comparing to the most recent PEG derivatives (Veronese, Caliceti, Schiavon, 1997; Gokarn, McLean, Laue, 2012). Nonetheless, bifunctional PEGs may significantly increase viscosity compared to the originator drug formulation since one reactive PEG molecule can conjugate to two different protein molecules, resulting in protein cross linking and a hydrogel formation. In addition, linear PEGs of large molecular weight may impede the appropriate release of small molecular weight protein drugs, preventing them to reach therapeutic concentrations at the target sites (when a cleavable PEG is employed) (Roberts, Bentley, Harris, 2012). To overcome these drawbacks, several novel types 
of PEG derivatives have been synthesized, including Y-shaped PEGs, forked PEGs and multi-arm PEGs (Figure 3) (Roberts, Bentley, Harris, 2012; Pfister, Morbidelli, 2014). Y-shaped PEGs have an "umbrella like" structure, linking two linear PEG derivatives to active groups of amino acids. This structure provides better protection than linear PEGs toward antibodies recognition and cleavage by proteolytic enzymes. This PEG variant was tested in several proteins (i.e. ribonuclease, catalase, asparaginase, trypsin, among others), but is not applied as frequently for peptides and small molecules drugs (Monfardini et al., 1995).

Forked PEGs provide multi-proximal reactive groups at one or both ends of a linear PEG chain (Veronese, Caliceti, Schiavon, 1997). The first report on a forked PEG synthesis dates from 1999 (Harris, Kozlowski, 1999); it refers to the attachment to the terminus of the polymer backbone of a trifunctional linker, such as serinol or $\beta$-glutamic acid. Forked PEGs are useful for conjugating small molecules rather than proteins since conjugation of forked PEGs functionalized at both ends of the polymer chain generate protein hydrogels rather than soluble PEGylated proteins. Nonetheless, forked PEGs may find application in biobetters' design attached to Fab' antibody fragments to produce a conjugate similar in structure to the full-length antibody (Constantinou, Chen, Deonarain, 2010) Multi-arm PEGs are star-like structures carrying multi-hydroxyl or functional groups, increasing the amount of active sites and molecular weight
(Kim et al., 2016). Similarly to fork-shaped PEGs, multiarm PEGs are not much explored in the attachment with proteins due to protein cross-link. They have been widely investigated for conjugation of small molecule drugs such as NKTR-102 (PEG-irinotecan) (Adkins et al., 2015), EZN-2208 (PEG-SN38) (Garrett et al., 2013) and NKTR214 (PEG- aldesleukin) (Charych et al., 2016), which are some examples of PEGylated drugs that have entered into clinical trials.

PEGylation processes may be classified in "firstgeneration" and "second-generation". First-generation processes involved random PEGylation, what results in multiple isoforms with a lack of control in the physicochemical and pharmaceutical properties of the final product (i.e. presence of mixtures of isomers with batch-to-batch variation and unstable bonds). Despite these limitations, first-generation PEGylated drugs are still in use today. Instead, the second-generation PEGylated biomolecules are obtained with novel PEG derivatives (Figure 3 ) including higher molecular weight and branched structures. In comparison to linear PEG, branched PEGylation decreases immunogenicity and increases half-life, but usually the decrease in activity of the biomolecules is more pronounced. Novel trends in PEGylation recognise a "third generation" technology, aiming to preserve the drug's bioactivity, using novel non-linear PEG derivatives and alternative PEGylation strategies (Swierczewska, Lee, Lee, 2015) that will be further discussed below.

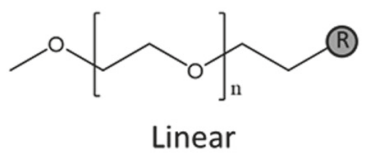

(R)<smiles>[C+]CCC(C)OCC(C)(C)C</smiles><smiles>CCOCCOCCCOCCOCC</smiles>

Y-shaped

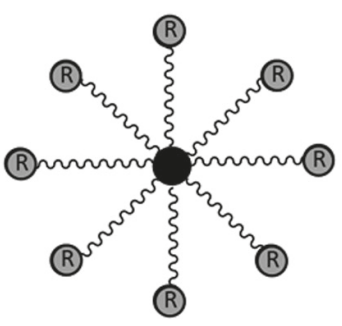

Multi-arm

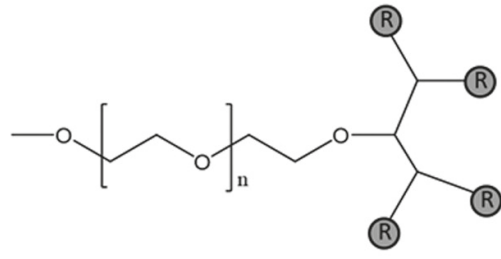

Fork-shaped PEG

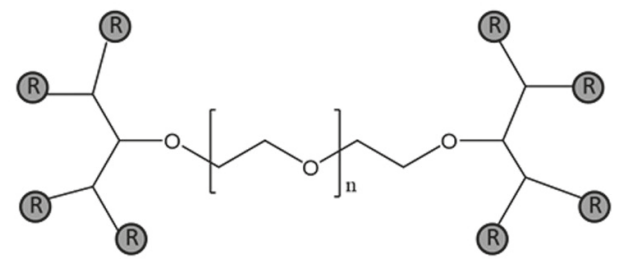

Fork-shaped PEG2

FIGURE 3 - Reactive PEGs used in PEGylation reactions. R represents functional groups of PEG derivatives. Linear - simplest and most often used conjugate agent with only one reactive group; Bifunctional - linear PEG derivative with two reactive groups; Y-shaped PEG - two linear PEG derivatives linked to a single point of attachment to proteins; Fork-shaped PEG - multi-proximal reactive groups at the end of one or both ends of a linear PEG chain; Multi-arm PEG - an eight-arm PEG carrying multi-hydroxyl or other functional groups $(\mathrm{R})$ with pentaerythritol, hexaglycerol, or tripentaerythritol as the central core. 
Several sites of proteins can be targeted for PEGylation (Figure 4) and in the next subsections we will explore different PEGylation strategies that can be applied in the development of novel biobetters.

\section{PEGylation of $\varepsilon$-amino groups}

Amine groups are present in large quantities on the surface of most therapeutic proteins as lysine residues or $\mathrm{N}$-terminals and PEGylation of lysine $\varepsilon$-amino groups is the most studied type of PEGylation (Figure 5). It may be performed via the $\mathrm{N}$-alkylation or $\mathrm{N}$-acylation by using the activated PEG carbonates or carboxylates (Pasut, Veronese, 2012; Zhang et al., 2012).

The main drawback of this approach is low selectivity of PEG position since after the random attachment to some lysine residues, steric hindrance may occur in neighbouring lysine residues. (Pfister, Morbidelli, 2014) This leads to a significant variation in the number of chains introduced and their location, resulting in a mixture of heterogeneous isomers (Ginn et al., 2014) with batch-to-batch variation. The first two proteins to be PEGylated were adenosine deaminase (ADA) and asparaginase, with $5 \mathrm{kDa}$ succinimidyl succinate-activated
PEG (mPEG-SS): pegademase (Adagen $®, ~ 11-17$ PEG molecules) and pegaspargase (Oncaspar®, 69-82 PEG molecules) (Turecek et al., 2016).

It is known that arginine residues are less prone to reaction with the reactive PEG due to delocalization of charge in the guanidinium group. Thus, molecular strategies such as replacement of lysine by arginine at essential sites often result in proteins with retention of activity and more controlled PEGylation at $\varepsilon$-amino groups. The reverse way, i.e. the replacement of some neutral residues by lysine at non-essential sites, add new regions for PEGylation. These strategies controls the number of possible PEGylation sites and may result in more homogeneous PEGylated preparations (Pasut, Veronese, 2012; Zhang et al., 2012).

\section{PEGylation of thiols groups}

Thiol groups are very suitable for site-specific PEGylation since specific covalent conjugation is possible even in the presence of other protein nucleophiles (Ginn et al., 2014) and the reduction of protein activity is usually lower. Few PEGylated thiol groups can already improve the pharmacokinetic properties of therapeutic

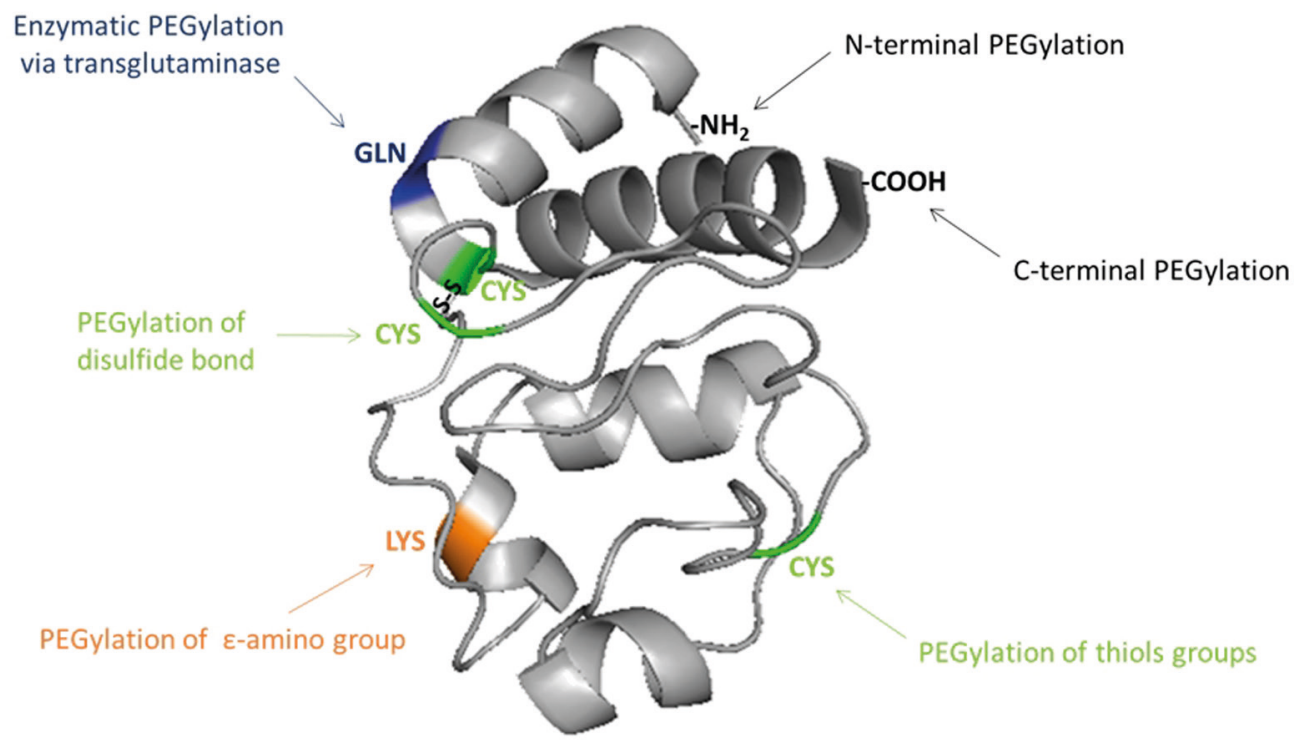

FIGURE 4 - Potential sites of PEGylation in proteins. Typical reactive amino-acids including lysine, cysteine, glutamine, $N$-terminal amino group and the $C$-terminal carboxylic acid are specific sites for conjugation with PEG derivatives.

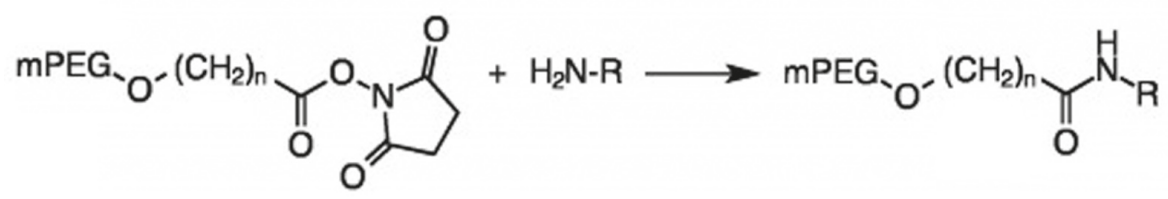

FIGURE 5 - PEGylation of primary amines in proteins, forming an amide linkage. 
proteins (Zhang et al., 2012). The PEGylation agents most commonly used are maleimide PEGs such as orthopyridyl disulphide (PEG-OPSS) and tosylate (PEG-TS) to form a thioether bond by a Michael addition (Pasut, Veronese, 2012; Pfister, Morbidelli, 2014). The reaction $\mathrm{pH}$ should be carefully buffered at values bellow lysine residues $\mathrm{pKa}$ (usually 9.3 to 10.5 ) to avoid the coupling of protein amine groups to maleimide (Pasut, Veronese, 2012).

The main limitation of this technique is that proteins rarely present cysteine residues in reduced form; they are generally involved in disulfide bonds. When present, reduced cysteine residues are located mainly in inaccessible hydrophobic domains and for that reason present low reactivity (Pasut, Veronese, 2012; Pfister, Morbidelli, 2014). This problem can be overcome using genetic engineering tools to insert one or more free cysteine residues on the protein surface to facilitate sitespecific PEGylation (Constantinou, Chen, Deonarain, 2010). CIMZIA $®$ is a PEGylated anti-TNF recombinant antibody Fab fragment, the only FDA approved protein with thiol group PEGylation (Figure 6). It is approved for treatment of rheumatoid arthritis, Crohn's disease, and axial spondyloarthritis. CIMZIA ${ }^{\circledR}$ is produced in E. coli bacterium and covalently bound with $40-\mathrm{kDa}$ branched PEG at a cysteine residue, which was inserted three amino acids from the $C$-terminus of the heavy chain antibody fragment by genetic engineering.(Turecek et al., 2016)

\section{PEGylation of disulfide bond}

Recently, the disulfide bonds were considered as targets for site-specific PEGylation, mainly as a way to overcome the lack of free cysteines in protein (Pfister, Morbidelli, 2014). Its applicability in therapeutic protein PEGylation is still under investigation, but it is known that disulfide bridges are present in small amounts in therapeutic proteins, making PEGylation at these sites attractive due to the possibility of obtaining homogeneous conjugates. However, the natural distance between the sulfur atoms must be preserved with PEGylation since these bonds are essential for protein conformation (Pasut, Veronese, 2012). The technique was first proposed by Brocchini et al. (Brocchini et al., 2006) using bis-thiol alkylating PEG reagent capable to form a three-carbon bridge after reducing the disulfide bonds of the protein. The mild reduction of the accessible native disufide bonds enable site-specific PEGylation in the sulfur atoms, while retaining the protein tertiary structure (Figure 7) (Pasut, Veronese, 2012; Kolate et al., 2014).

\section{N-terminal and C-terminal PEGylation}

N-terminal PEGylation is considered a site-directed reaction (Ginn et al., 2014), since there is only one group per protein chain and the number of PEGylation sites are dramatically reduced (Pfister, Morbidelli, 2014). The reaction selectivity is based on $\mathrm{pKa}$ differences between the $\varepsilon$-amino group of lysine residues (9.3-10.5) and the $\mathrm{N}$-terminal $\alpha$-amino group of proteins (7.6 to 8). Accordingly, at $\mathrm{pH}$ values lower than 9.3 the lysine residues will be predominantly protonated and unavailable to react with active PEG (Pasut, Veronese, 2012). In some

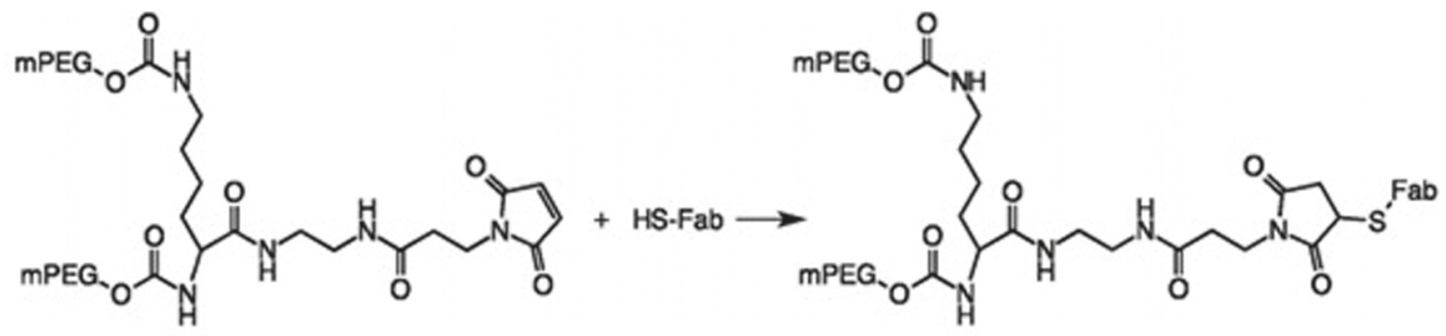

FIGURE 6 - Schematic conjugation of thiol PEGylation from antibody fragment with a PEG maleimide reagent (representing CIMZIA ${ }^{\circledR}$ conjugation).

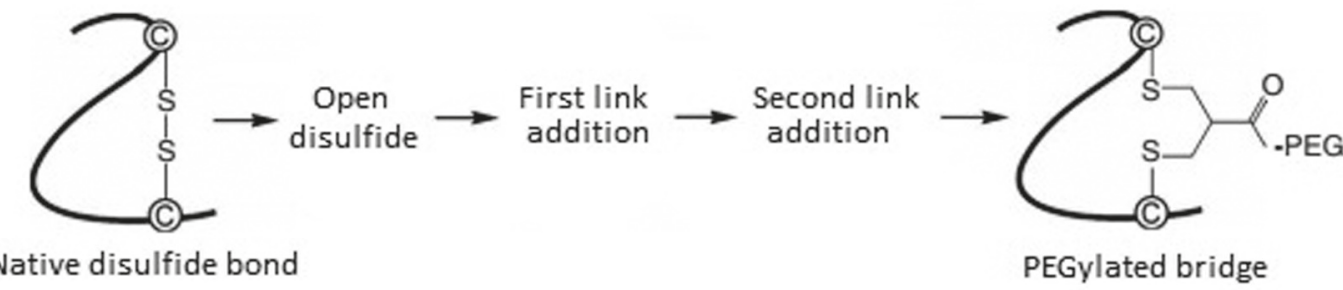

FIGURE 7 - Schematic mechanism for a disulfide site-specific PEGylation. 
cases, the determination of the optimal $\mathrm{pH}$ conditions can be difficult since small changes may result in competition for other amine groups and optimum $\mathrm{pH}$ varies between proteins (Ginn et al. 2014). Molecular strategies can be used to improve selectivity, such as depletion or modification of some lysine residues on the protein surface (by chemical or genetic engineering) and functionalization of the N-terminal portion with reactive carbonyl groups that are more selective and efficient (Ginn et al., 2014; Pfister, Morbidelli, 2014). Neulasta ${ }^{\circledR}$ (Pegfilgrastim) and Plegridy ${ }^{\circledR}($ Peginterferon $\beta-1)$ are two examples of protein N-terminal PEGylation with $20 \mathrm{kDa}$ PEG.

In the same way, each protein chain has one C-terminal portion that can be used for site-specific PEGylation. This reaction can be performed by introducing a hydrazine group at this location by fusion technique with inteins (Pasut, Veronese, 2012; Kolate et al., 2014). An intein is a protein segment that is self-excised through a process known as protein splicing (Kolate et $a l ., 2014)$. The conjugation reactions include the intein excision resulting in the protein of interest containing one hydrazine group at the C-terminal portion, which can react specifically with PEG molecules functionalized with aldehyde groups or ketone (Pasut, Veronese, 2012). This approach has been recently applied to IFN- $\alpha$ (Pasut, Veronese, 2012; Ginn et al., 2014; Kolate et al., 2014) and IFN- $\beta$ (Thom et al., 2011), however, none PEGylated conjugate by this technique reached the stage of clinical research (Ginn et al., 2014).

\section{Enzymatic PEGylation}

This site-specific PEGylation is based on a transglutaminase (TGase) catalysed acyl transfer reaction between glutamine residues (Gln) and PEG primary amino groups in reactive PEGs (Figure 8) (Sato, 2002). For chimeric proteins, a short sequence of Gln residues is incorporated at the protein terminal by genetic engineering, without disturbing its flexibility and conformation, and then PEGylated with primary amine derivatives of PEGs in the presence of the enzyme. Compared with other strategies, TGase mediated conjugations were found to be more site-specific, reproducible and versatile (Fontana et al., 2008). Enzymatic PEGylations with TGase were already investigated for several proteins, such as apomyoglobin (apoMb), human growth hormone (hGH), $\alpha$-lactalbumin ( $\alpha$-LA), human interlukin-2 (hIL-2) and human granulocyte colony-stimulating factor (hG-CSF) (Fontana et al., 2008; Mero et al., 2009).

\section{Released and non-covalent PEGylation}

One of the main drawbacks of protein PEGylation is the activity loss of therapeutic proteins. One solution is to target amino acids in non-essential sites, but it is often necessary laborious protein engineering tools that can bring conformational changes in protein structure (Gong, Leroux, Gauthier, 2015). The reversible attachment of PEG polymer to the protein might be interesting to obtain conjugates with longer half-life while keeping pharmacodynamic properties (Pfister, Morbidelli, 2014). Some of the reactions for reversible PEGylation include bicine linker, histidine PEGylation, glucose and different ligands ("linkers") that are cleaved by serum proteases (Nollmann et al., 2013) and other enzymes, especially via $\beta$-elimination reaction (Figure 9). An important requirement is that the linker does not leave any residue on the protein after cleavage of the bond. Pharmacodynamic response must also be controlled and optimized (Pasut, Veronese, 2012; Gong, Leroux, Gauthier, 2015).

Non-covalent PEGylation, in turn, is based in hydrophobic interactions (Pasut, Veronese, 2012), coordination complex formation (Mero et al., 2011), protein-polyelectrolyte and protein-block copolymers complexes (Kurinomaru, Shiraki, 2015). Research on this particular type of PEGylation has increased in recent years
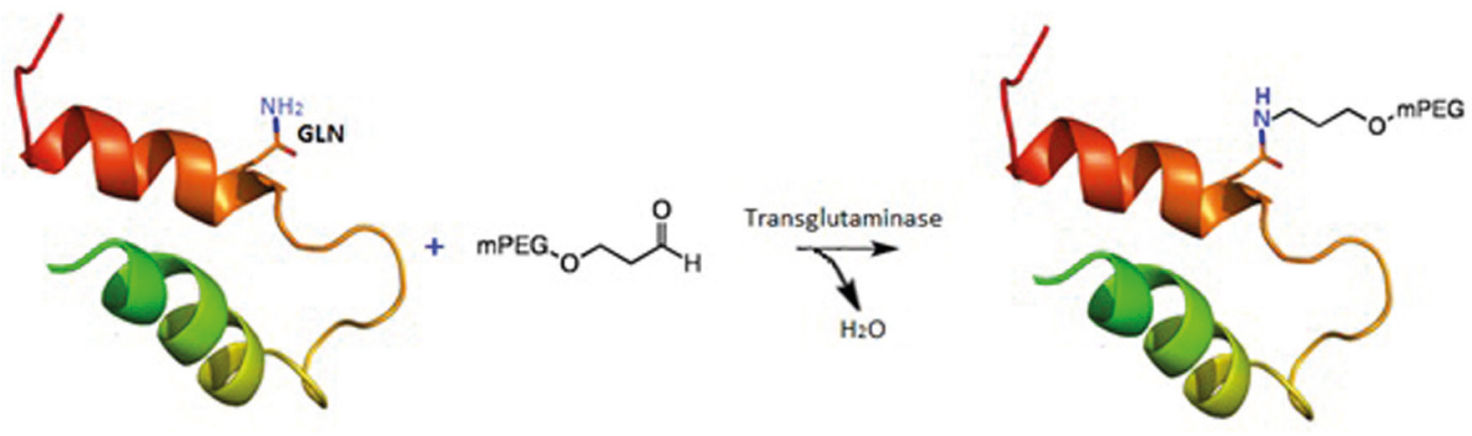

FIGURE 8 - Site-specific PEGylation of protein with transglutaminase (TGase) strategy, where GLN residue are PEGylated in the presence of TGase. 


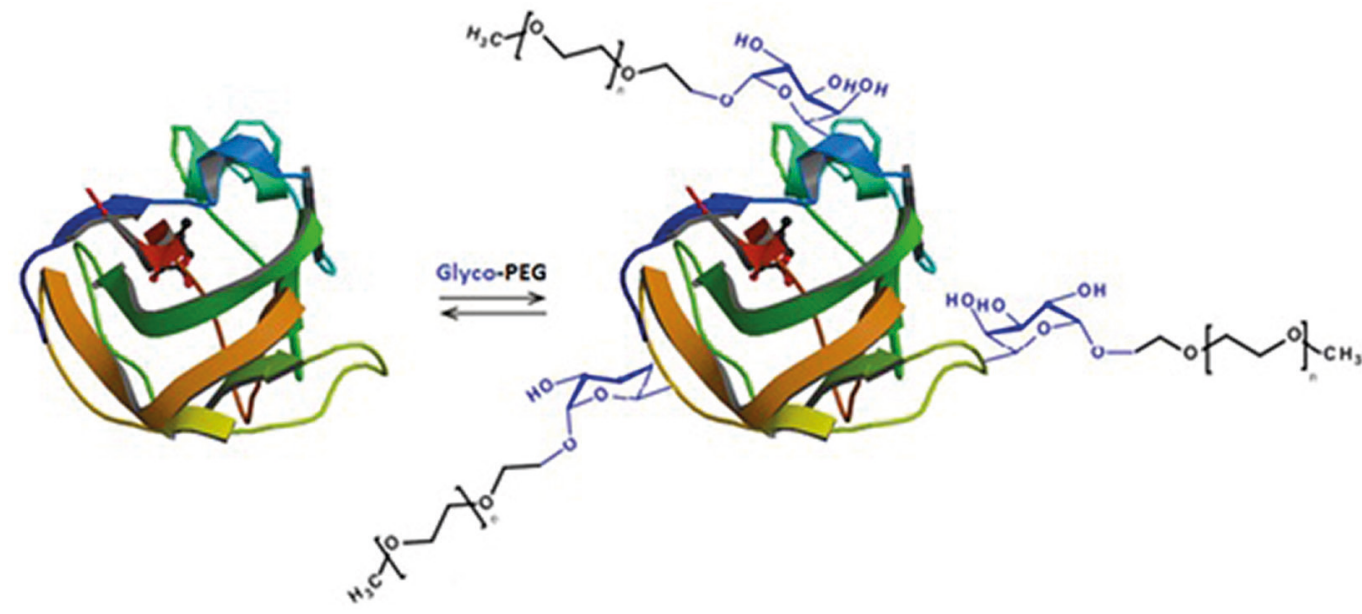

FIGURE 9 - Schematic representation of a reversible PEGylation with Glyco-PEG.

and promising results have been observed, but a more extensive study is still needed, especially to demonstrate significant improvement in pharmacokinetic properties (Pfister, Morbidelli, 2014).

One of the main disadvantages of this type of PEGylation refers to the release of the protein during purification steps or during storage, which is inherent to non-covalent conjugates. To avoid cleavage during storage, additional techniques such as lyophilization are required. This can be a challenge due to the difficulty of preserving PEGylated protein structure/activity during the freezing step (Pasut, Veronese, 2012; Kolate et al., 2014).

\section{CURRENT ADVANCES IN THE PURIFICATION OF PEGYLATED PROTEINS}

PEGylation reactions commonly result in heterogeneous mixtures of unreacted protein, PEGylated conjugates and undesired PEGamers (proteins with varying number of attached PEG molecules) (Yoshimoto, Yamamoto, 2012; Moosmann, Müller, Böttinger, 2014). Furthermore, PEGylated conjugates dissimilar among themselves may be formed, with different number of grafted chains, length and attaching sites. Therefore, efficient downstream strategies are needed to purify these complex mixtures for commercial approval (Yoshimoto, Yamamoto, 2012). Purification of PEGylated proteins implies three main challenges: (i) isolation and recycling of the unreacted protein from the PEGylated proteins, (ii) isolation of each PEGylated protein form from the reaction media (e.g. PEG derivate, undesired PEGamers and other reagents such as hydroxylamine), and (iii) fractionation of PEGylated conjugates based on the degree of PEGylation. This multifaceted challenge is not easy to overcome since PEG-protein conjugates are structurally similar to the originator protein (González-Valdez, Rito-Palomares, Benavides, 2012). A combination of chromatographic (Moosmann, Müller, Böttinger, 2014) and/or non-chromatographic (Mayolo-Deloisa et al., 2011) techniques is usually designed for each PEGylation process, exploiting the physicochemical properties of the molecules present in the PEGylation reaction mixture. In the last years, chromatographic fractionation platforms have been commonly used in downstream processes of PEGylated proteins (Fee, 2003; Moosmann et al., 2010; 2014; Müller et al., 2010; Mayolo-Deloisa et al., 2012), as shown in Figure 10. Non-chromatographic techniques have been suggested alternatively in the recent years, since they can exhibit advantages such as high versatility, ease of scale-up and low overall cost and time of processing (Cramer, Holstein, 2011). However, these are not fully characterized for the fractionation and analysis of PEGylated conjugates (Mayolo-Deloisa et al., 2011). Currently, efforts are being made to characterize and optimize those purification platforms for a larger spectrum of PEGylated proteins (Mayolo-Deloisa et al., 2011; Galindo-López, Rito-Palomares, 2013).

\section{Chromatographic fractionation platforms}

As mentioned above, most part of the purification processes for PEGylated proteins are based on chromatographic techniques, especially size exclusion chromatography (SEC) (Maiser et al., 2015) and ion exchange chromatography (IEX) (Zhao et al., 2012). SEC is a chromatographic method in which molecules in solution are separated by molecular weight (MW). It is well recognized that SEC can be used to separate PEGylated species from unreacted protein and other components, but the effectiveness will greatly depend upon 


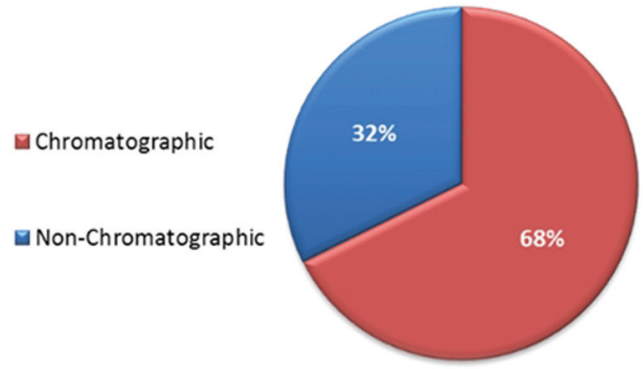

aSEC

口IEX

$\square \mathrm{HIC}$

Capillary electrophoresis

Membrane separations

$\square$ Aqueous biphasic systems

Microfluidics

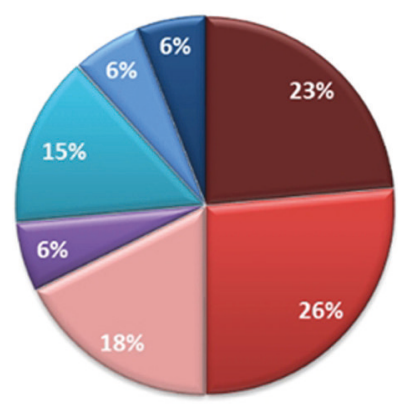

FIGURE 10 - Distribution of the publications/papers reported in the last 7 years $(>2010)$ dealing with chromatographic and nonchromatographic techniques for the separation of PEGylated proteins in Web of Science and Pubmed databases. SEC - size exclusion chromatography, IEX - ion exchange chromatography, $\mathrm{HIC}$ - hydrophobic interaction chromatography.

the molecular size of the species involved (Silva Freitas, Abrahao-Neto, 2010). For instance, the conjugation of a single PEG polymer with a protein with the same MW more than double the protein molecular radius, due to the steric elongation of PEG chains (Fee, Van Alstine, 2011). Therefore, native and mono-PEGylated proteins should be readily separable by SEC (Fee, Van Alstine, 2004). Nonetheless, the resolution among chromatographic peaks lowers as PEGylation extent increases, due to the presence of more PEGylated conjugates (Fahrländer et al., 2015; Maiser et al., 2015). SEC is not able to purify the positional isomers of PEGylated conjugates, due to the minimal radius differences among these protein species (Fee, Van Alstine, 2011). Proteins of different degrees of PEGylation may be separated by IEX since for each PEG molecule attached to an amino group, for example, a PEGylated protein has one less positive charge and this chromatographic technique separates proteins based on net surface charge (Fee, Van Alstine, 2011). By choosing the optimal ion exchanger and separation conditions, high resolution can be obtained. The best protocol must be achieved case-by-case depending on the specific protein and type of PEGylation (Fee, Van Alstine, 2011). In the recent years, IEX has been the most used downstream technique for the separation of PEGylated conjugates (Figure 10) (Abe et al., 2010; Moosmann et al., 2012; Zhao et al., 2012; Morgenstern et al., 2017). The major challenge of IEX refers to the fact that PEG chains sterically interfere in the interaction of the protein charged residues and the ionic exchange support, producing a masking effect of the charges (Fee, Van Alstine, 2011).

Hydrophobic interaction chromatography (HIC) is also used to fractionate PEGylated proteins (Müller et al., 2010; Mayolo-Deloisa et al., 2012; Moosmann, Müller, Böttinger, 2014), although not so extensively as IEX and SEC. HIC takes advantage of the hydrophobicity changes through PEGylation process, separating PEGylated conjugates based on the relative hydrophobicity/ hydrophilicity (Fee, Van Alstine, 2011). However, HIC has low capacity and poor resolution between adjacent peaks. To date, it is not possible to conclude which type of chromatographic technique is the best option to fractionate PEGylated conjugates. Furthermore, there is no generalized chromatographic protocols to purify PEGylated proteins, separation strategies must be developed on a case-by-case basis (Fee, Van Alstine, 2011; Mayolo-Deloisa et al., 2011).

\section{Non-chromatographic fractionation platforms}

The non-chromatographic fractionation platforms applied in the purification of PEGylated proteins are: capillary electrophoresis (CE), membrane separation techniques (ultrafiltration, diafiltration and dialysis) and aqueous biphasic systems (ABS) (Mayolo-Deloisa et al., 2011). Membrane separation processes are the simplest among all non-chromatographic techniques currently used and are based on the molecular weight and hydrodynamic radius of the proteins. PEGylated species can be efficiently fractionated and recovered using ultrafiltration and diafiltration (Cheang, Zydney, 2003; Ruanjaikaen, Zydney, 2011). However, ultrafiltration methods may generate high product losses, particularly when using membranes with pores considerably smaller than the hydrodynamic radius of the PEGylated protein (Kwon, Molek, Zydney, 2008). Even though membrane separation techniques are not able to separate conjugates according to their positional isomerism, they present certain advantages, such as costs, over SEC and IEX. Capillary electrophoresis (CE) proved to be a powerful tool for the high-resolution separation of different PEGylated products; it has been used in the analysis and small-scale purification of PEGylated proteins (Li et al., 2001; $\mathrm{Na}$ et al., 2008; Lee, Na, 2010). The major advantages of this technique are its automation capability, low sample consumption and short-time 
process (Caslavska, Thormann, 2004). On the other hand, CE lacks in the industrial process due to technique scaleup incapability.

To overcome the main drawbacks of nonchromatographic downstream processes, the use of microfluidic devices is emerging as a promising strategy for high-throughput monitoring of protein PEGylation purification. The design of these novel devices for rapid separation, concentration, and recovery of PEGylated proteins in a one-step operation is a current trend for nonchromatographic downstream processes (Yoshimoto, Yamamoto, 2012; Mata-Gómez et al., 2016).

Aqueous biphasic systems offer a great alternative of an efficient downstream processing platform for PEGylated proteins due to their versatility, ease of scale up and low costs (Santos et al., 2017). Several works addressed the application of ABS as purification tools to be used in the separation of PEGylated proteins (Delgado et al., 1994; González-Valdez et al., 2011; GonzálezValdez, Rito-Palomares, Benavides, 2013; Santos et al., 2017). Delgado et al. (1994) used PEG/dextran ABS to characterize the degree of PEGylation (n) in mixtures of PEG-protein conjugates of bovine serum albumin and granulocyte-macrophage colony stimulating factor. These authors determined the relationship between the increase in partition coefficient $(\mathrm{K})$ of the PEGylated conjugate with the degree of PEGylation of the protein species present in the resulting mixtures. GonzálezValdez et al. (2011) studied PEG/salt-based ABS for the separation of native RNase $\mathrm{A}$ and lactoalbumin and their respective PEGylated conjugates. The results indicated the potential of ABS for the fractionation of PEGylated proteins from the respective unreacted proteins. However the sub-fractionation of PEGylated proteins from themselves (depending on the degree of PEGylation) was not achieved. Extended applications of ABS were achieved with the combination of this technique with continuous scale-up platforms, such as the counter current distribution ABS (CCD-ABS). The application of CCD-ABS was already performed for the fractionation of PEGylated forms of lysozyme and RNase (Sookkumnerd, Hsu, 2000; Galindo-López, RitoPalomares, Benavides, 2013).

Despite the advances reported, other types of ABS, such as PEG/polyacrylate (with or without electrolytes present), PEG/ionic liquids, copolymer/salt are worth investigating for the fractionation of PEGylated conjugates with different degrees of PEGylation. In situ product recovery through $\mathrm{ABS}$ in continuous regime and the application of other approaches regarding continuous flow purification, namely the centrifugal partition chromatography (CPC), should also be focused in the near future (Mayolo-Deloisa et al., 2011).

\section{CHARACTERIZATION OF PEGYLATED PRO- TEINS}

To obtain a valid PEGylation reaction and to characterize/quantify PEGylated conjugates, several analytical techniques must be applied. These techniques must be adapted to the specific polymer-protein conjugates and be able to access their (i) structural arrangement, (ii) bioactivity potential and (iii) stability.

In terms of structural analysis of the PEGylated conjugates, it is important to determine the molecular mass, the number of bound polymer chains, the specific sites of PEG attachment and the secondary and tertiary structure (González-Valdez, Rito-Palomares, Benavides, 2012). Together with UV-visible spectrophotometry and electrophoresis, size exclusion chromatography (SEC), mass spectrometry (MS), fourier-transform infrared spectroscopy (FTIR), circular dichroism (CD) and dynamic light scattering (DLS) are the major techniques used to characterize the molecular mass and structure of PEGylated proteins and are of great prominence in biobetters manufacturing and quality control.

Generally, the first step for structural characterization is polyacrylamide gel electrophoresis (PAGE), and/or western blotting to confirm the identity of the PEGylated protein (Zhou, He, Wang, 2016). However, PEG may change the electrophoretic mobility, which complicates size characterization, being this technique of low precision (González-Valdez, Rito-Palomares, Benavides, 2012). The mass of PEGylated species is commonly evaluated by MS, which is also capable of identifying the specific sites and number of attached polymer chains in the primary amino acid sequence (Domon, Aebersold, 2006). MALDITOF MS has been employed the technique of choice to characterize average molecular weight and degree of PEGylation (Chowdhury, Doleman, Johnston, 1995; Bullock, Chowdhury, Johnston, 1996; Wang et al., 2002; $\mathrm{Na}$, Youn, Lee, 2004; Yun et al., 2005). Irrespectively of the size and type of PEG used (mono and heterofunctional, linear or branched), MALDI provides first-rate information on molecular weight, total amount and distribution of PEG on protein, besides site specific information on PEGylation coupling site (Cindrić et al., 2007). On the other hand, electrospray ionization MS (ESI-MS) have been gaining attention in the past decade for the analysis of PEGylated proteins (Cindrić et al., 2007; Forstenlehner et al., 2014). Compared to MALDI, ESI-MS has some advantages such as automated workflow and reduced sample preparation 
time (Gioacchini et al., 1997). Yet, the overlapping protein charge pattern and the polydispersity of the PEGylation derivatives make it difficult to understand and analyse the ESI-MS spectrum. Some additional techniques have been alternatively employed, namely tryptic digestion (Wu et $a l ., 2011)$ and isotopically labelled internal standards of PEGylated proteins (Watson et al., 1994). SEC can also bee applied to infer the size of PEGylated proteins (Fee, Van Alstine, 2004). However, some studies suggest that the determination of PEGylated proteins mass through this technique is not as adequate as using MS (Fee, Van Alstine, 2004; González-Valdez, Rito-Palomares, Benavides, 2012). The apparent PEG interaction with the material of SEC columns could lead to anomalously slow elution times of PEGylated proteins and, thus, incorrect molecular weight determinations (Fee, Van Alstine, 2004).

After the confirmation of the PEGylated protein mass and polydispersity, the effect of PEGylation in the secondary and tertiary structure of the protein should be evaluated and CD spectroscopy is a powerful technique for this end. Through far UV CD (data collected from $\sim 190$ to $250 \mathrm{~nm}$ ) and near UV CD (data collected from 250 to $300 \mathrm{~nm}$ ) it is possible to infer about the protein secondary and tertiary structure, respectively. Additionally, CD can also be used to study protein stability as a function of temperature or denaturing conditions. FTIR spectroscopy can be alternatively used to evaluate the effect of PEG on the protein secondary structure, however it is less sensitive than CD (Rajan et al., 2006).

The hydrodynamic diameter of PEGylated proteins is also of importance to identify different PEG-protein conjugates and it can be estimated based on DLS measurements (Gokarn, McLean, Laue, 2012). DLS is the most conventional method for determination and characterization of nanoparticles. In PEGylation, usually the hydrodynamic diameter of a conjugate is increased by the addition of PEGs in the protein (at least up to three PEG molecules) (Gokarn, McLean, Laue, 2012).

The determination of a PEGylated protein biological activity is one of the most important steps for characterization (Fontana et al., 2008; Jevševar, Kunstelj, Porekar, 2010; González-Valdez, Rito-Palomares, Benavides, 2012). For enzymes, in particular, kinetic parameters must be determined (e.g. $\mathrm{K}_{\mathrm{m}}, \mathrm{k}_{\mathrm{cat}}$ and vmax). Additionally, in vivo bioactivity must be confirmed for PEGylated proteins. A decrease in PEGylated protein activity can be observed depending on the reaction site, since the covalent attachment of PEG impairs restrictions in molecular conformation (Hsieh, Lin, 2015; Morgenstern et al., 2017). Other methods currently used to quantify biological activity involve bioassays, immunoassays, and radioassays. Finally, stability assays are crucial to identify the most stable PEGylated isoform as a promising biobetter. Protein stability assessment should be performed considering the thermostability (Santiago-Rodríguez et al., 2011; Hsieh, Lin, 2015), long term stability (SantiagoRodríguez et al., 2011), pH stability (Tian et al., 2013) and proteolytic digestion assays (Kurinomaru, Shiraki, 2015).

Overall, a protein PEGylation process to develop a biobetter can be defined as a multi-step approach (Figure 11), in which the complete analysis of the technological and economical benefits of each step should be attained to make it viable to pharmaceutical and biotechnological industries.

\section{CONCLUSIONS}

PEGylation is an attractive and prospective tool to improve drug properties, especially protein drugs. Despite all molecular biology tools available today, it is still one

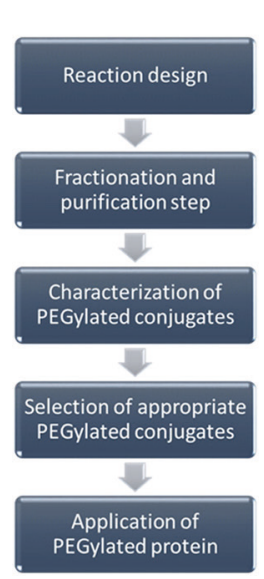

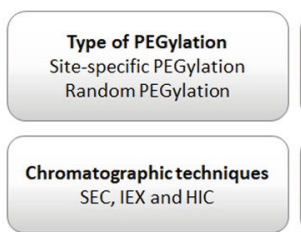

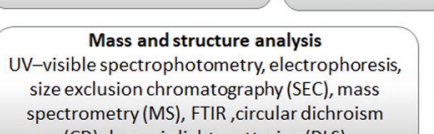
(CD) dynamic light scattering (DLS)

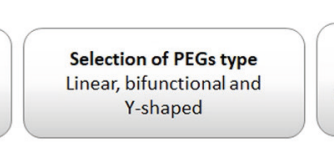
Experimental conditions
ph, reaction time, molar ratio
and agitiation speed

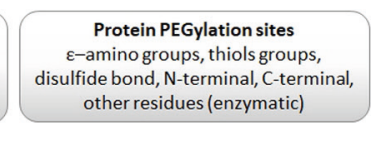

Non-chromatographic techniques capillary electrophoresis, membrane separations, ueous biphasic systems and microfluidics devices
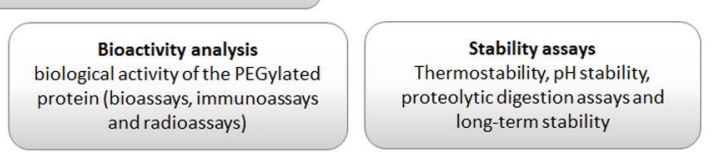
ong-term stability

Protein Biobetter

Reduced immunogenicity, less accessibility for proteolytic degradation, enhanced circulation half-life and stability and decreased aggregation

FIGURE 11 - Flow diagram of the PEGylation bioprocess operation from reaction design to purification and characterization, ending up with the final application of the chemically modified protein drugs as an effective biobetter. 
of the main strategies for biobetters development. The overall process must be considered to develop a PEGylated protein, from the chemical reaction to the proper PEGylated protein purification, what can be considered the PEGylation downstream step. The reaction step involves proper selection of the PEGylation reagents and chemistry, what is crucial for the final product characteristics and its application. There is no better chemistry, it will depend on the protein drug characteristics, such as if it need to be detached from PEG to present activity and for how long it should circulate in the body. After the reaction, downstream steps will include the fractionation and purification of PEG-protein conjugates, followed by the complete structural and activity characterization of the resulting species. High degree of purity is needed for protein drugs and for this reason it is hard to imagine industrial purification processes without including the chromatographic steps already in use. Nonetheless, the complete analysis of the technological and economic benefits of PEGylation could support biopharmaceutical industries in seeking for more efficient strategies to develop biobetters.

\section{ACKNOWLEDGMENTS}

The authors acknowledge the National Council for Scientific and Technological Development (CNPq - Brazil), the Coordination for the Improvement of Higher Education Personnel (CAPES-Brazil), the São Paulo Research Foundation (FAPESP - Brazil, grant \# 2016/22065-5) and the Portuguese Foundation for Science and Technology (FCT) for the doctoral grant SFRH/ BD/102915/2014 to J. H. P. M. Santos. This work was developed within the scope of the project CICECO-Aveiro Institute of Materials, POCI-01-0145-FEDER-007679 (FCT Ref. UID /CTM/50011/2013), financed by national funds through the FCT/MEC and when appropriate co-financed by FEDER under the PT2020 Partnership Agreement.

\section{REFERENCES}

Abe M, Akbarzaderaleh P, Hamachi M, Yoshimoto N, Yamamoto S. Interaction mechanism of mono-PEGylated proteins in electrostatic interaction chromatography. Biotechnol J. 2010;5(5):477-483.

Abuchowski A, van Es T, Palczuk NC, Davis FF. Alteration of immunological properties of bovine serum albumin by covalent attachment of polyethylene glycol. J Biol Chem. 1977;252(11):3578-3581
Adkins CE, Nounou MI, Hye T, Mohammad AS, Terrell-Hall T, Mohan NK, et al. NKTR-102 Efficacy versus irinotecan in a mouse model of brain metastases of breast cancer. BMC Cancer. 2015;15:685.

Barbosa MDFS, Kumar S, Loughrey H, Singh SK. Biosimilars and biobetters as tools for understanding and mitigating the immunogenicity of biotherapeutics. Drug Discov Today. 2012;17(23-24):1282-1288.

Beck A, Sanglier-Cianférani S, Van Dorsselaer A. Biosimilar, biobetter, and next generation antibody characterization by mass spectrometry. Anal Chem. 2012;84(11):4637-4646.

Brocchini S, Balan S, Godwin A, Choi JW, Zloh M, Shaunak S. PEGylation of native disulfide bonds in proteins. Nat Protoc. 2006;1(5):2241-2252.

Bullock J, Chowdhury S, Johnston D. Characterization of poly(ethylene glycol)-modified superoxide dismutase: Comparison of capillary electrophoresis and matrix-assisted laser desorption/ionization mass spectrometry. Anal Chem. 1996;68(18):3258-3264.

Calo-Fernández B, Martínez-Hurtado JL. Biosimilars: Company strategies to capture value from the biologics market. Pharmaceuticals. 2012;5(12):1393-1408.

Caslavska J, Thormann W. Monitoring of drugs and metabolites in body fluids by capillary electrophoresis with XeHg lampbased and laser-induced fluorescence detection. Electrophoresis. 2004;25(10-11):1623-1631.

Charych DH, Hoch U, Langowski JL, Lee SR, Addepalli MK, Kirk PB, et al. NKTR-214, an engineered cytokine with biased IL2 receptor binding, increased tumor exposure, and marked efficacy in mouse tumor models. Clin Cancer Res. 2016;22(3):680-690.

Cheang B, Zydney AL. Separation of alpha-lactalbumin and beta-lactoglobulin using membrane ultrafiltration. Biotechnol Bioeng. 2003;83(2):201-209.

Chowdhury SK, Doleman M, Johnston D. Fingerprinting proteins coupled with polymers by mass spectrometry: Investigation of polyethylene glycol-conjugated superoxide dismutase. J Am Soc Mass Spectrom. 1995;6(6):478-487. 
Cindrić M, Čepo T, Galić N, Bukvić-Krajacić M, Tomczyk N, Vissers JP, et al. Structural characterization of PEGylated $\mathrm{rHuG}$ CSF and location of PEG attachment sites. J Pharm Biomed Anal. 2007;44(2):388-395.

Constantinou A, Chen C, Deonarain MP. Modulating the pharmacokinetics of therapeutic antibodies. Biotechnol Lett. 2010;32(5):609-622.

Cramer SM, Holstein MA. Downstream bioprocessing: Recent advances and future promise. Curr Opin Chem Eng. 2011;1(1):27-37.

Da Silva Freitas D, Mero A, Pasut G. Chemical and enzymatic site specific pegylation of hGH. Bioconjug Chem. 2013;24(3):456463.

Delgado C, Malik F, Selisko B, Fisher D, Francis GE. Quantitative analysis of polyethylene glycol (PEG) in PEGmodified proteins/cytokines by aqueous two-phase systems. J Biochem Biophys Methods. 1994;29(3-4):237-250.

Domon B, Aebersold R. Mass spectrometry and protein analysis. Science. 2006;312(5771):212-217.

Fahrländer E, Schelhaas S, Jacobs AH, Langer K. PEGylated human serum albumin (HSA) nanoparticles: preparation, characterization and quantification of the PEGylation extent. Nanotechnology. 2015;26(14):145103.

Fee CJ. Size-exclusion reaction chromatography (SERC): A new technique for protein PEGylation. Biotechnol Bioeng. 2003;82(2):200-206.

Fee CJ, Alstine JM Van. Separation of PEGylated Proteins by Size Exclusion Chromatography: Influence of PEGylation on Molecular Size. APCChE Conf. 2004;1-10.

Fee CJ, Van Alstine JM. Purification of PEGylated proteins. in: protein purification: principles, high resolution methods, and applications. Third Edition. 2011; p 339-362.

Fee CJ, Van Alstine JM. Prediction of the viscosity radius and the size exclusion chromatography behavior of PEGylated proteins. In: Bioconjugate Chemistry. 2004; p 1304-1313.

Fontana A, Spolaore B, Mero A, Veronese FM. Site-specific modification and PEGylation of pharmaceutical proteins mediated by transglutaminase. Adv Drug Deliv. Rev. 2008;60(1):13-28.
Forstenlehner IC, Holzmann J, Scheffler K, Wieder W, Toll H, Huber CG. A direct-infusion-and HPLC-ESI-orbitrap-MS approach for the characterization of intact pegylated proteins. Anal Chem. 2014;86(1):826-834.

Galindo-López M, Rito-Palomares M. Practical nonchromatography strategies for the potential separation of PEGylated RNase A conjugates. J Chem Technol Biotechnol. 2013;88(1):49-54.

Garrett CR, Bekaii-Saab TS, Ryan T, Fisher GA, Clive S, Kavan $\mathrm{P}$, et al. Randomized phase 2 study of pegylated SN-38 (EZN2208 ) or irinotecan plus cetuximab in patients with advanced colorectal cancer. Cancer. 2013;119(24):4223-4230.

Ginn C, Khalili H, Lever R, Brocchini S. PEGylation and its impact on the design of new protein-based medicines. Future Med Chem. 2014;6(16):1829-1846.

Gioacchini AM, Carrea G, Secundo F, Baraldini M, Roda A. Electrospray mass spectrometric analysis of poly(ethylene glycol)-protein conjugates. Rapid Commun Mass Spectrom. 1997;11(11):1219-1222.

Gokarn YR, McLean M, Laue TM. Effect of PEGylation on protein hydrodynamics. Mol Pharm. 2012;9(4):762-773.

Gong Y, Leroux JC, Gauthier MA. Releasable Conjugation of polymers to proteins. Bioconjug Chem. 2015;26(7):1179-1181.

González-Valdez J, Cueto LF, Benavides J, Rito-Palomares M. Potential application of aqueous two-phase systems for the fractionation of RNase A and $\alpha$-Lactalbumin from their PEGylated conjugates. J Chem Technol Biotechnol. 2011;86(1):26-33.

González-Valdez J, Rito-Palomares M, Benavides J. Advances and trends in the design, analysis, and characterization of polymer-protein conjugates for "PEGylaided" bioprocesses. Anal Bioanal Chem. 2012;403(8):2225-2235.

González-Valdez J, Rito-Palomares M, Benavides J. Effects of chemical modifications in the partition behavior of proteins in aqueous two-phase systems: A case study with RNase A. Biotechnol Prog. 2013;29(2):378-385.

Gorham H. The Value of Biobetters. PRA Heal Sci. 2015;62:471489. https://prahs.com/resources/whitepapers/The_Value_of Biobetters.pdf. 
Harris JM, Kozlowski A. Poly (ethylene glycol) derivatives with proximal reactive groups. 1999; WO 99/45964.

Hoffman AS. The early days of PEG and PEGylation (1970s-1990s). Acta Biomater;2016;40:1-5.

Hsieh YP, Lin SC. Effect of PEGylation on the activity and stability of horseradish peroxidase and L-N-carbamoylase in aqueous phases. Process Biochem. 2015;50(9):1372-1378.

Jevševar S, Kunstelj M, Porekar VG. PEGylation of therapeutic proteins. Biotechnol J. 2010;5(1):113-128.

Kim J, Kong YP, Niedzielski SM, Singh RK, Putnamb AJ, Shikanov A. Characterization of the crosslinking kinetics of multi-arm poly(ethylene glycol) hydrogels formed via Michaeltype addition. Soft Matter. 2016;12:2076-2085.

Kolate A, Baradia D, Patil S, Vhora I, Kore G, Misra A. PEG - A versatile conjugating ligand for drugs and drug delivery systems. J Control Release. 2014;192:67-81.

Kuriakose A, Chirmule N, Nair P. Immunogenicity of biotherapeutics: causes and association with posttranslational modifications. J Immunol Res. 2016;2016:1298473.

Kurinomaru T, Shiraki K. Noncovalent PEGylation of L-asparaginase using PEGylated polyelectrolyte. J Pharm Sci. 2015;104(2):587-592.

Kwon B, Molek J, Zydney AL. Ultrafiltration of PEGylated proteins: Fouling and concentration polarization effects. J Memb Sci. 2008;319(1-2):206-213.

Lee KS, Na DH. Capillary electrophoretic separation of poly(ethylene glycol)-modified granulocyte-colony stimulating factor. Arch Pharm Res. 2010;33(3):491-495.

Li W, Zhong Y, Lin B, Su Z. Characterization of polyethylene glycol-modified proteins by semi-aqueous capillary electrophoresis. J Chromatogr A. 2001;905(1-2):299-307.

Maiser B, Baumgartner K, Dismer F, Hubbuch J. Effect of lysozyme solid-phase PEGylation on reaction kinetics and isoform distribution. J Chromatogr B Anal Technol Biomed Life Sci. 2015;1002:313-318.
Mata-Gómez MA, Gallo-Villanueva RC, González-Valdez J, Martínez-Chapa SO, Rito-Palomares. Dielectrophoretic behavior of PEGylated RNase A inside a microchannel with diamond-shaped insulating posts. Electrophoresis. 2016;37:519528.

Mayolo-Deloisa K, González-Valdez J, Guajardo-Flores D, Aguilar O, Benavides J, Rito-Palomares M. Current advances in the non-chromatographic fractionation and characterization of PEGylated proteins. J Chem Technol Biotechnol. 2011;86(1):1825.

Mayolo-Deloisa K, Lienqueo ME, Andrews B, Rito-Palomares M, Asenio JA. Hydrophobic interaction chromatography for purification of monoPEGylated RNase A. J Chromatogr A. 2012;1242:11-16.

Mero A, Ishino T, Chaiken I, Veronese FM, Pasut G. Multivalent and flexible PEG-nitrilotriacetic acid derivatives for noncovalent protein pegylation. Pharm Res. 2011;28(10):2412-21.

Mero A, Spolaore B, Veronese FM, Fontana A. Transglutaminasemediated PEGylation of proteins: Direct identification of the sites of protein modification by mass spectrometry using a novel monodisperse PEG. Bioconjug Chem. 2009;20(2):384-389.

Monfardini C, Schiavon O, Caliceti P, Morpurgo M, Harris JM, Veronese FM. A branched monomethoxypoly(ethylene glycol) for protein modification. Bioconjug Chem. 1995;6(1):62-69.

Moosmann A, Christel J, Boettinger H, Mueller E. Analytical and preparative separation of PEGylated lysozyme for the characterization of chromatography media. J Chromatogr A.2012;1217(2):209-215.

Moosmann A, Müller E, Böttinger H. Purification of PEGylated Proteins, with the example of PEGylated lysozyme and PEGylated scFv. Methods Mol Biol. 2014;1129:527-538.

Morgenstern J, Baumann P, Brunner C, Hubbuch J. Effect of PEG molecular weight and PEGylation degree on the physical stability of PEGylated lysozyme. Int J Pharm. 2017;519(12):408-417.

Müller E, Josic D, Schröder T, Moosmann A. Solubility and binding properties of PEGylated lysozyme derivatives with increasing molecular weight on hydrophobic-interaction chromatographic resins. J Chromatogr A. 2010;1217(28):4696703. 
Na DH, Park EJ, Jo YW, Lee KC. Capillary electrophoretic separation of high-molecular-weight poly(ethylene glycol)modified proteins. Anal Biochem. 2008;373(2):207-212.

Na DH, Youn YS, Lee KC. Matrix-assisted laser desorption/ ionization time-of-flight mass spectrometry for monitoring and optimization of site-specific PEGylation of ricin A-chain. Rapid Commun Mass Spectrom. 2004;18:2185-2189.

Nanocs. Succinimidyl PEG NHS, mPEG-NHS(SC) [Internet]. 2007. Available at: http://www.nanocs.net/mPEG-SC-5k-1g. htm.

Nollmann FI, Goldbach T, Berthold N, Hoffmann R. Controlled systemic release of therapeutic peptides from PEGylated prodrugs by serum proteases. Angew Chem Int Ed Engl. 2013;52(29):7597-7599.

Palm T, Esfandiary R, Gandhi R. The effect of PEGylation on the stability of small therapeutic proteins. Pharm Dev Technol. 2011;16(5):441-448.

Pasut G, Veronese FM. State of the art in PEGylation: The great versatility achieved after forty years of research. J Control Release. 2012;161(2):461-472.

Pfister D, Morbidelli M. Process for protein PEGylation. J Control Release. 2014;180:134-149.

Rajan RS, Li T, Aras M, Sloey C, Sutherland W, Arai H, et al. Modulation of protein aggregation by polyethylene glycol conjugation: GCSF as a case study. Protein Sci. 2006;15(5):1063-1075.

Roberts MJ, Bentley MD, Harris JM. Chemistry for peptide and protein PEGylation. Adv Drug Deliv Rev. 2012;64(4):116-127.

Ruanjaikaen K, Zydney AL. Purification of singly PEGylated $\alpha$-lactalbumin using charged ultrafiltration membranes. Biotechnol Bioeng. 2011;108(4):822-829.

Ryu JK, Kim HS, Nam DH. Current status and perspectives of biopharmaceutical drugs. Biotechnol Bioprocess Eng. 2012;17(5):900-911.

Santiago-Rodríguez L, Méndez J, Flores-Fernandez GM, Pagán M, Rodríguez-Martínez JA, Cabrera CR, et al. Enhanced stability of a nanostructured cytochrome c biosensor by PEGylation. J Electroanal Chem. 2011;663(1):1-7.
Santos JHPM, Carretero G, Coutinho JAP, Rangel-Yagui CO, Ventura SPM. Multistep purification of cytochrome c PEGylated forms using polymer-based aqueous biphasic systems. Green Chem. 2017;19:5800-5808.

Sassi AB, Nagarkar R, Hamblin P. Biobetter biologics. In: Singh M, Salnikova M, editors. Novel Approaches and strategies for biologics, vaccines and cancer therapies. Academic Press: Elsevier. 2015; p. 199-217.

Sato H. Enzymatic procedure for site-specific pegylation of proteins. Adv Drug Deliv Rev. 2002;54(4):487-504.

Silva FD, Abrahao-Neto J. Batch purification of high-purity lysozyme from egg white and characterization of the enzyme modified by PEGylation. Pharm Biol. 2010;48(5):554-562.

Sookkumnerd T, Hsu JT. Purification of PEG-protein conjugates by countercurrent disturbution in aqueous two-phase systems. J Liq Chromatogr Relat Technol. 2000;23(4):497-503.

Spadiut O, Capone S, Krainer F, Glieder A, Herwig C. Microbials for the production of monoclonal antibodies and antibody fragments. Trends Biotechnol. 2014;32(1):54-60.

Swierczewska M, Lee KC, Lee S. What is the future of PEGylated therapies? Expert Opin Emerg Drugs. 2015;20(4):531-536.

Thom J, Anderson D, McGregor J, Cotton G. Recombinant protein hydrazides: Application to site-specific protein PEGylation. Bioconjug Chem. 2011;22(6):1017-1020.

Tian H, Guo Y, Gao X, Yao W. PEGylation enhancement of $\mathrm{pH}$ stability of uricase via inhibitive tetramer dissociation. J Pharm Pharmacol. 2013;65(1):53-63.

Transparency Market Research Global Biologics Market Will be Worth US\$479, 752 Million by 2024; Global Industry Analysis, Size, Share, Growth, Trends, and Forecast 2016 2024: TMR. [Internet] New York; 2016. Available at: https:// www.prnewswire.com/news-releases/global-biologics-marketwill-be-worth-us479-752-million-by-2024-global-industryanalysis-size-share-growth-trends-and-forecast-2016---2024tmr-596150181.html.

Turecek PL, Bossard MJ, Schoetens F, Ivens IA. PEGylation of biopharmaceuticals: a review of chemistry and nonclinical safety information of approved drugs. J Pharm Sci. 2016;105(2):460475. 
Veronese FM. Peptide and protein PEGylation: a review of problems and solutions. Biomaterials. 2001;22(5):405-417.

Veronese FM, Caliceti P, Schiavon O. Branched and linear poly(ethylene glycol): influence of the polymer structure on enzymological, pharmacokinetic, and immunological properties of protein conjugates. J Bioact Compat Polym. 1997;12:196207.

Wang YS, Youngster S, Grace M, Bausch J, Bordens R, Wyss DF. Structural and biological characterization of pegylated recombinant interferon alpha- $2 \mathrm{~b}$ and its therapeutic implications. Adv Drug Deliv Rev. 2002;54(4):547-570.

Watson E, Shah B, DePrince R, Hendren RW, Nelson R. Matrixassisted laser desorption mass spectrometric analysis of a pegylated recombinant protein. Biotechniques. 1994;16(2):278281.

Wu ST, Ouyang Z, Olah TV, Jemal M. A strategy for liquid chromatography/tandem mass spectrometry based quantitation of pegylated protein drugs in plasma using plasma protein precipitation with water-miscible organic solvents and subsequent trypsin digestion to generate surrogate peptides for detection. Rapid Commun Mass Spectrom. 2011;25(2):281-290.
Yoshimoto N, Yamamoto S. PEGylated protein separations: Challenges and opportunities. Biotechnol J. 2012;7(5):592-593.

Yun Q, Chen T, Zhang G, Bi J, Ma G, Su Z. Novel polyethylene glycol derivative suitable for the preparation of mono-PEGylated protein. Biotechnol Lett. 2005;27(3):213-217.

Zhang C, Yang XL, Yuan YH, Pu J, Liao F. Site-specific PEGylation of therapeutic proteins via optimization of both accessible reactive amino acid residues and PEG derivatives. BioDrugs. 2012;26(4):209-215.

Zhao T, Yang Y, Zong A, Tan H, Song X, Meng S, et al. N-terminal PEGylation of human serum albumin and investigation of its pharmacokinetics and pulmonary microvascular retention. Biosci Trends. 2012;6(2):81-88.

Zhou JQ, He T, Wang JW. PEGylation of cytochrome c at the level of lysine residues mediated by a microbial transglutaminase. Biotechnol Lett. 2016;38(7):1121-1129. 